Aquaculture

November 2015, Volume 448, Pages 569-577

http://dx.doi.org/10.1016/j.aquaculture.2015.06.029

http://archimer.ifremer.fr/doc/00271/38246/

(c) 2015 Published by Elsevier B.V.

\title{
Selection for muscle fat content and triploidy affect flesh quality in pan-size rainbow trout, Oncorhynchus mykiss
}

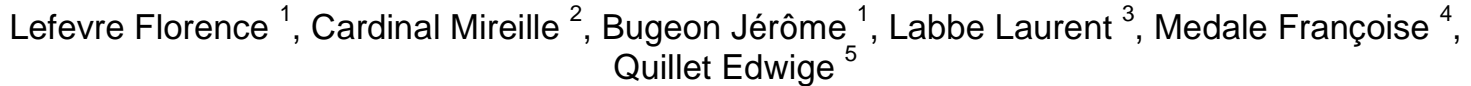

1 INRA, UR1037, LPGP, IFR 140, Rennes, F-35042, France

2 Ifremer, BRM-STBM, rue de l'île d'Yeu, BP 21105, Nantes Cedex 3, F-44311 France

3 INRA, UE0937, PEIMA, Sizun, F-29450 France

${ }^{4}$ INRA, UR1067, NuMeA, Saint-Pée-sur-Nivelle, F-64310 France

${ }^{5}$ INRA, UMR1313, GABI, Jouy-en-Josas, F-78350 France

* Corresponding author : Florence Lefevre, email address : florence.lefevre@rennes.inra.fr

\begin{abstract}
:
A lean muscle line (L) and a fat muscle line (F) of rainbow trout were established (Quillet et al., 2005) by a two-way selection for muscle lipid content performed on pan-size rainbow trout using a nondestructive measurement of muscle lipid content (Distell Fish Fat Meter®). The aim of the present study was to evaluate the consequences of this selective breeding on flesh quality of pan size $(290 \mathrm{~g})$ diploid and triploid trout after three generations of selection. Instrumental evaluations of fillet color and $\mathrm{pH}$ measurement were performed at slaughter. Flesh color, $\mathrm{pH}$, dry matter content and mechanical resistance were measured at $48 \mathrm{~h}$ and $96 \mathrm{~h}$ postmortem on raw and cooked flesh, respectively. A sensorial profile analysis was performed on cooked fillets. Fillets from the selected fatty muscle line $(F)$ had a higher dry matter content and were more colorful for both raw and cooked fillets. Mechanical evaluation indicated a tendency of raw flesh from $\mathrm{F}$ fish to be less firm, but this was not confirmed after cooking, neither instrumentally or by sensory analysis. The sensory analysis revealed higher fat loss, higher intensity of flavor of cooked potato, higher exudation, higher moisture content and a more fatty film left on the tongue for flesh from $\mathrm{F}$ fish. Triploid fish had mechanically softer raw and cooked fillets, but the difference was not perceived by the sensorial panel. The sensorial evaluation also revealed a lower global intensity of odor, more exudation and a higher moisture content in the fillets from triploid fish. These differences in quality parameters among groups of fish were associated with larger white muscle fibers in $\mathrm{F}$ fish and in triploid fish. The data provide additional information about the relationship between muscle fat content, muscle cellularity and flesh quality.
\end{abstract}




\section{Highlights}

- Two-way selection for muscle lipid content affected rainbow trout fillet quality, including color and some textural parameters. For the first time, a comparison was performed between high and low muscle fat fish without the confounding effect of fish size or diet. Selective breeding was shown to affect fish muscle characteristics other than fat content, such as muscle fiber size, that could contribute to organoleptic flesh quality. The effect of selective breeding was similar in diploid and triploid fish, indicating the efficiency of selection with diploid fish to be applied for larger triploid fish.

Keywords : flesh quality, lipid content, muscle fiber, triploid, fish, texture 


\section{Introduction}

One of the main challenges for fish farmers is product quality control in order to meet consumer demand. The amount of muscle fat content in a fish is a key feature, as it determines the nutritional and organoleptic qualities of the flesh (Medale et al., 2003; Robb et al., 2002). The muscle lipid content directly influences the flesh nutritional quality, as fish products are the main source of polyunsaturated fatty acids, which are known to be beneficial for human health (Das et al., 2009; Daviglus et al., 1997; Medale et al., 2003). In addition, the fish muscle lipid content also affects fish flesh sensorial quality, especially flavor and texture. A higher muscle lipid content leads to a more flavored product with an increased perception of a fishy or oily flavor but a decreased perception of some other flavors (Chaiyapechara et al., 2003b; Robb et al., 2002). An effect of the muscle lipid content on the flavor of smoked fillet is also generally observed in salmonids (Mørkøre et al., 2001; Robb et al., 2002).

A positive effect of higher muscle fat content on fillet color is often observed when instrumental evaluation of color is performed (Mørkøre et al., 2001; Nickell and Bromage, 1998), although this difference is not systematically detected by a sensory panel (Regost et al., 2001a). The positive correlation observed between fillet lipid content and astaxanthin content in Coho salmon fed diets with different lipid levels may account for this difference in color (Chan et al., 2002). The effect of muscle fat content on flesh texture is nevertheless still a matter of debate. Some studies have documented a softer flesh in fattier fish (Fauconneau et al., 1993; Green-Petersen and Hyldig, 2010; Johansson et al., 2000; Robb et al., 2002; Thakur et al., 2003), while other studies have not documented softer flesh (Regost et al., 2001a). Nevertheless, a limited difference in muscle fat content between the groups used for comparison may explain why no effect was recorded in some studies.

The two main ways to control farmed animal whole body adiposity in fish, and as a consequence, muscle fat content, are through feeding (diet quantity and composition) and 
selective breeding (Weil et al., 2013). Increasing the lipid levels in fish feed leads to a higher whole body fat content and a higher muscle fat content. This is particularly true for fatty fish, such as salmonids, rainbow trout (Chaiyapechara et al., 2003a; Corraze et al., 1999), brown trout (Regost et al., 2001a) and Atlantic salmon (Solberg, 2004), but not for lean fish, such as turbot (Regost et al., 2001b). Increased carbohydrate levels are also an efficient way to increase the storage of energy as lipids in the fillet and abdominal fat in salmonids (Aksnes, 1995; Corraze et al., 1999).

The second way to control body fat content and distribution is selective breeding (Bell et al., 2010; Quillet et al., 2005; Tobin et al., 2006). In rainbow trout, two generations of divergent selection muscle fat content produced a lean line (L) and a fat line (F), with the mean muscle lipid content increased by $15 \%$ to $31 \%$ in the large fish of the F line, depending on the diet (Quillet et al., 2007). Further experiments with fish from the third generation of selection showed that the lines differed in fat allocation between visceral adipose tissue and muscle (Kolditz et al., 2008). These lines offer a unique model to analyze the effect of distinct muscle lipid content on flesh quality by comparing fish of the same age with comparable body weight and with the same feed composition and ration.

Triploidy is commonly used in rainbow trout rearing to avoid fish sexual maturation and the subsequent loss of flesh quality (including the reduction of muscle lipid content) in large fish. Few works have reported the effect of triploidy on fish muscle characteristics and flesh quality. However, cells from triploid fish are generally larger than those from diploid fish, including muscle cells. Oxygen transport is also affected by larger erythrocytes and higher amount of hemoglobin in triploid fish, which may affect muscle cell metabolism (Atkins and Benfey, 2008). These effects of triploidy on fish biology may lead to consequences in flesh quality, as reported in various salmonid species. Differences between diploid and triploid fish were demonstrated in muscle fiber size, fillet gaping, color, texture and some muscle 
biochemical characteristics, such as protein solubility (Bjørnevik et al., 2004; Gomez-Guillén et al., 2000; Poontawee et al., 2007; Werner et al., 2008).

The objective of this study was to evaluate whether the selection for muscle fat content and ploidy affect fillet quality in rainbow trout. The compared fish were obtained after 3 generations of selection, as described in Quillet et al. (2005), and after they had reached the same mean body weight. Such a model allows the comparison of flesh quality for fish with comparable feeding rates and composition.

\section{Material and Methods}

\subsection{Fish and rearing conditions}

Rainbow trout were reared in the INRA's experimental facilities (PEIMA, Sizun, France). Three generations of divergent selection for high (F) or low (L) muscle fat content was performed using a non-destructive method (Distell Fish Fatmeter ${ }^{\circledR}$ ) in live fish (Quillet et al., 2007).

Diploid and triploid fish were obtained by splitting each line into two batches. One half was incubated without treatment, and the other half was subjected to hydrostatic pressure shock 40 min after fertilization ( 700 bars during $3 \mathrm{~min}$ at $10^{\circ} \mathrm{C}$ ) to induce triploid formation ( $3 \mathrm{n}$ group) according to Chourrout (1984).

The fish were 1 year old at slaughter and were first reared in triplicate in spring water at a steady temperature $\left(\approx 12^{\circ} \mathrm{C}\right)$ for 4.5 months. Then, the fish were reared in triplicate in circular $2 \mathrm{~m}$ diameter tanks containing $1.8 \mathrm{~m}^{3}$ water from the "Drennec" Lake (Sizun, France). The water temperature fluctuated seasonally from $6^{\circ} \mathrm{C}$ to $18^{\circ} \mathrm{C}$. The water inlet to each tank was independent to allow "in-flow" adjustment. The water flow was adjusted to 2 tanks renewal per hour to allow an oxygen concentration above $6 \mathrm{mg} / \mathrm{l}$ and enable the disposal of fish waste. Routinely, $10 \%$ of the fish from each tank were weighed every 3 weeks. The fish were fed 5 times a day with a commercial diet composed of $51 \%$ protein and $23 \%$ lipids during the first 6 
months and then with a diet composed of $45 \%$ protein, $25 \%$ lipid until the end of the experiment. Both diets were made of fish meal and fish oil as raw materials and manufactured by an aquafeed producer. The ration level was calculated and adjusted each week. The amount of food distributed was increased by $10 \%$ compared to the usual ration tables to ensure that the fish were fed to satiation.

The fish fasted for $48 \mathrm{~h}$ before slaughter. For instrumental measurements of quality, trout were harvested as fast as possible with a handling net, anesthetized with 2-phenoxyethanol $(0.3 \mathrm{ml} / \mathrm{l})$ in a separate tank and bled by gill arch section. All the slaughter measurements were performed immediately after death, within less than $1 \mathrm{~h}$ using 15 fish per replicate (45 fish per experimental group). Five fish per replicate (15 per group) were measured for quality parameters at $48 \mathrm{~h}$ postmortem. For the sensory analysis, 45 fish per group were killed by a blow to the head, bled by gill arch section, eviscerated, put in box with ice and transported to the IFREMER Laboratory (Nantes, France), where they were stored in a cold room at $4^{\circ} \mathrm{C}$ until the sensorial analysis.

\subsection{Measurements at slaughter}

The fish traits measurements were indexed according to the ontology ATOL (Animal Trait Ontology for Livestock, http://www.atol-ontology.com/index.php/en/les-ontologiesen/visualisation-en, Golik et al., 2012).

The muscle lipid content (ATOL:0001663) assessment was the first measurement conducted on whole fish using the Torry Fish Fat Meter ${ }^{\circledR}$ (Distell Industries Ltd, Scotland). This tool is based on the microwave transmission evaluation of water content and allows the indirect evaluation of fish muscle lipid content. The fish were wiped with paper tissue to remove excess water and mucus. The instrument was firmly applied on the dorsal musculature, parallel to the lateral line, between the head and the dorsal fin of both sides of the fish (Douirin et al., 1998). The fat value was the mean of these two measurements. 
Individual body weight (BW, ATOL:0000351) and fork length (L, ATOL:0001658) were measured. The condition factor (ATOL:0001653) was calculated as $\mathrm{K}=\mathrm{BW} / \mathrm{L}^{3}$.

The fish were eviscerated and filleted. The fillet color (ATOL:0001017) was assessed using a portable Minolta Chromameter CR-200 (Minolta, France) equipped with light source C and a $2^{\circ}$ observer angle, calibrated to a white standard. For each fillet, two measurements were taken on the interior part of the fillet, one anterior to the dorsal fin and the other anterior to the anal fin. The mean of these two measurements values was considered. Data were expressed using the $\mathrm{L}^{*}, \mathrm{a}^{*}, \mathrm{~b}^{*}$ system, representing lightness, redness, and yellowness, respectively, as recommended by CIE (1976).

The muscle initial pH (ATOL:0001684) was measured in the front part of the fillet within 30 min and 1 hour postmortem using a Hanna HI 9025C pH meter (Hanna Instruments Srl, Italy) equipped with a Hanna FC200 penetration electrode (Hanna Instruments Srl, Italy). The fillet temperature (ATOL:0000067) was measured simultaneously to correct the $\mathrm{pH}$ values.

Fillets were packed in plastic bags within 1 hour after fish death and stored on ice until further analysis at $48 \mathrm{~h}$ postmortem.

\subsection{Muscle histological analysis}

Deep white muscle samples were taken within one hour after fish death, just beneath the dorsal fin. The samples were fixed in Carnoy fixative (absolute ethanol, chloroform, acetic acid, 6:3:1) for $48 \mathrm{~h}$ at $4^{\circ} \mathrm{C}$, dehydrated in alcohol and alcohol/butanol and embedded in paraffin. Sample sections $(10 \mu \mathrm{m})$ were then cut and stained with Sirius Red and Fast Green $0.1 \%$ in saturated picric acid (Lopez-De Leon and Rojkind, 1985). Five microscopic fields, presenting fibers with transversal sections, were digitized for each histological section. The areas of the transversal section of individual white muscle fibers (300-500 fibers per fish) were measured using Visilog 5.4 for Windows. Histological treatments, including paraffin embedding, cause muscle fiber shrinkage. Therefore, the individual muscle fiber area was 
multiplied by a shrinkage correction (SC) factor calculated as follows: $\mathrm{SC}=($ total image area- connective tissue area)/(fiber total area)). The muscle fiber diameters (D)

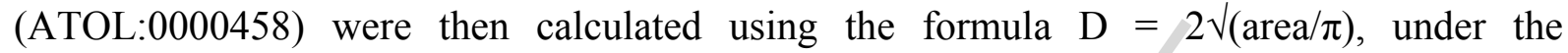
assumption that the individual fiber cross-sections were circular.

\subsection{Physical measurements of quality parameters measured at $48 \mathrm{~h}$ (raw) and $96 \mathrm{~h}$} (cooked) postmortem

At $48 \mathrm{~h}$ postmortem, physical measurements of the quality parameters were performed on one raw fillet, whereas the second fillet was cooked. The fillet mean weight was approximately 50 g. Fillets without skin were cooked 1 to $2 \mathrm{~min}$, depending on their weight, in a domestic microwave oven (Samsung M192DN) at $450 \mathrm{~W}$ in a covered bowl to reach a core temperature of $65^{\circ} \mathrm{C}-70^{\circ} \mathrm{C}$. Fillets were then cooled to room temperature, packed in plastic bags and stored at $4{ }^{\circ} \mathrm{C}$ in a cold room until further analysis. Physical measurements of the quality parameters for the cooked fillets were assessed at $96 \mathrm{~h}$ postmortem, except for the color, which was evaluated immediately after cooking and cooling.

The fillet color was measured as previously described under the slaughter methods (Section 2.2).

The ultimate $\mathrm{pH}$ (ATOL:0001684) was measured with $5 \mathrm{~g}$ muscle, sampled in the anterior part of the fillet and homogenized in four volumes of distilled water.

The dry matter content (ATOL:0000101) was determined by drying approximately $5 \mathrm{~g}$ of minced fillet (anterior part) for $40 \mathrm{~h}$ in an oven at $105^{\circ} \mathrm{C}$. The mechanical strength (ATOL:0001649) of the middle part of the skinned fillet (64 mm length beneath the dorsal fin) was analyzed using a Kramer shear cell mounted on a static load cell of $2 \mathrm{kN}$ (INSTRON 5544, INSTRON Ltd., England). The fillet sample was completely sheared with shear blades perpendicular to the main axis of the fish (perpendicular to muscle fibers) at a speed of 1 $\mathrm{mm} / \mathrm{sec}$. The maximum force $(\mathrm{N})$ at low $(20 \%)$ and high $(80 \%)$ deformation and the work 
until the maximum force were calculated. All of these parameters were divided by the weight of the sample (Szczesniak et al., 1970).

\subsection{Sensory analysis}

Conventional profiling tests were carried out to characterize the sensory properties of the cooked fillets. The fish were filleted the day prior to the analysis. The fillets were rinsed with tap water $\left(15^{\circ} \mathrm{C}\right)$, covered with a plastic film to avoid any drying of the flesh surface and kept one day at $4^{\circ} \mathrm{C}$ before being cooked for the sensory test. The sensory evaluation was performed with the dorsal part of the fillets. Fillet portions of $50 \mathrm{~g}$ were cooked in a closed glass bowl in a microwave $(600 \mathrm{~W})$ for 1.5 minute. Samples were scored by a pool of 18 panelists belonging to the IFREMER staff who were already trained on the sensory descriptors for cooked fish. Sessions were performed in individual partitioned booths, according to the recommendations of ISO (1988), that were equipped with a computerized system (Fizz system, Biosystèmes, Dijon, France). Panelists received the samples just after cooking at a temperature of approximately $70^{\circ} \mathrm{C}$ and rated the sensory attributes on a continuous scale, from low intensity (0) to high intensity (10). The products were assigned 3digit numbers and were randomized for the order of presentation. The products were presented simultaneously at each session.

\subsection{Statistical analysis}

All of the results are expressed as the mean \pm standard deviation. For all of the parameters, except the sensory parameters, a two-way ANOVA was used to test the effects of line (L vs F) and ploidy ( $2 n$ vs $3 n$ ). The significant level was set at $p<0.05$. The significant differences between the mean values were determined using the Newman-Keuls test. The Pearson correlation coefficient was calculated to analyze the significance of the linear relationships between variables. All of the analyses were performed using Statistica for Windows (version 5.1) software. The number of fish, from 15 to 45 , measured for each parameter is specified in 
the tables. For the sensory analysis parameters, a three-way ANOVA was used to test the effects of the line, ploidy, and panelist on the sensory parameters. The significance of the differences $(\mathrm{p}<0.05)$ between the mean values was tested using a Duncan test, and the analyses were performed using Statgraphics Plus 5.1 software (Sigma Plus, Paris, France).

\section{Results}

\subsection{Fish and fillet characteristics at slaughter (Table 1)}

There was no difference observed in the fish body weights between groups. However, the condition factor $\mathrm{K}$ was higher $(\mathrm{p}<0.01)$ for fish from the $\mathrm{F}$ line than from the $\mathrm{L}$ line. As expected, the fat-meter values were consistently higher for fish from the F line when compared to fish from the L line $(\mathrm{p}<0.001)$. A significant effect of the line was found for the measure of fillet color immediately after slaughter. Fillets from the F fish gave higher values of lightness $\left(\mathrm{L}^{*}\right)$ and were more colorful, with higher values for redness $\left(\mathrm{a}^{*}\right)$ and yellowness $\left(b^{*}\right)(p<0.001)$. A significant effect of ploidy was observed on fillet lightness. The fillets from the triploid fish had higher values of $\mathrm{L}^{*}$ in both lines $(\mathrm{p}<0.05)$. No significant difference was found for the initial $\mathrm{pH}$ values in any group.

\subsection{Dry matter content, pH, and color of raw and cooked flesh at 48 h (raw) and 96 h (cooked) postmortem (Table 2)}

The dry matter content was higher for both the raw and cooked fillets from the F line when compared to those from the $\mathrm{L}$ line $(\mathrm{p}<0.001)$. There was no observed effect from the line or ploidy on the ultimate $\mathrm{pH}$ of the raw and cooked fillets. However, higher values of the ultimate $\mathrm{pH}$ were measured for raw flesh from triploid fish but not for cooked flesh. A significant effect $(\mathrm{p}<0.05)$ of both the line and ploidy was observed on the $\mathrm{pH}$ variation $(=$ initial $\mathrm{pH}-$ ultimate $\mathrm{pH}$ ), with a larger $\mathrm{pH}$ drop between slaughter and $48 \mathrm{~h}$ postmortem for the flesh of L line and for diploid fish.

The effect of selection observed at slaughter on fillet lightness was not observed $48 \mathrm{~h}$ 
postmortem. However, the significant effect of ploidy on lightness $\left(\mathrm{L}^{*}\right)$ was still significant ( $p<0.05)$, with higher values of $\mathrm{L}^{*}$ observed for fillets from triploid fish than for fillets of diploid fish (both raw and cooked fillets). Nevertheless, a significant interaction was obtained $(p<0.05)$ between the effects of selection and ploidy for cooked fillets, with a positive effect of ploidy on fillet lightness $\left(\mathrm{L}^{*}\right)$ observed in fish from the $\mathrm{L}$ line. The effects of selection on fillet color (redness $\mathrm{a}^{*}$ and yellowness $\mathrm{b}^{*}$ ) observed at slaughter were still significant $48 \mathrm{~h}$ postmortem for both raw and cooked fillets, with more colorful fillets for fish from the F line when compared to the $\mathrm{L}$ line fish.

\subsection{Mechanical resistance of raw and cooked fillets (Table 3)}

For raw flesh, a higher value for total work corrected by sample weight $(\mathrm{W} / \mathrm{w})$ was measured for fish fillets from the $\mathrm{L}$ line when compared to the $\mathrm{F}$ line. The same trend for higher mechanical resistance for fish fillets from the L line was also observed for specific resistance $($ Fmax $/ \mathrm{w})(\mathrm{p}=0.06)$. A significant effect of ploidy was measured for the mechanical resistance of the flesh, with higher values for diploid fish than for triploid fish $(\mathrm{p}<0.01$ for Fmax/w, and $\mathrm{p}<0.05$ for $\mathrm{W} / \mathrm{w})$. No effects of the line and ploidy were observed for the forces measured at the intermediate (both low and high) deformation.

After cooking, there was no longer a line effect on the mechanical resistance of the flesh. However, the ploidy induced a significant effect, with higher specific resistance (Fmax/w) and higher force at a low deformation $(\mathrm{F} 20 \% / \mathrm{w})$ for flesh from diploid fish than for flesh from triploid fish $(\mathrm{p}<0.05)$. The interaction between line and ploidy was observed on the mechanical resistance of the cooked flesh $(\mathrm{p}<0.05$ or $0.05<\mathrm{p}<0.10$, depending on the parameter). The differences between the diploids and triploids were enhanced in the $\mathrm{F}$ line. The effect of ploidy was significant in the F line and not significant in the L line.

\subsection{Muscle histological analysis (Table 4)}

The histological analysis of the white muscle fiber diameters showed that fish from the F line 
had muscle fibers with a higher mean diameter (MD) with fewer small fibers $(<20 \mu \mathrm{m})$ than fish from the $\mathrm{L}$ line $(\mathrm{p}<0.05)$. As a consequence, the fiber density (density = number of fibers per surface unit) was lower for fish from the F line. Ploidy also had a significant effect on the white muscle fiber size, with larger fibers and a higher percent (two-fold) of large fibers (> $100 \mu \mathrm{m})$ for triploid fish than for diploid fish $(\mathrm{p}<0.001)$.

\subsection{Sensory characteristics (Table 5)}

The trained panelists did not perceive an odor difference between the two fish lines. However, flesh from the two lines was found to significantly differ for some appearance, flavor and texture parameters. The flesh of trout from the F line had more fat droplets in the exudate $(\mathrm{p}<0.001)$, left a more fatty film on the tongue and had a more pronounced flavor of cooked potato than fish flesh from the L line. Fish flesh from the F line also appeared moister and had more exudation.

Fish ploidy had an impact on the flesh global odor intensity, which was lower for triploid fish than for diploid fish $(\mathrm{p}<0.001)$. Flesh exudation and moisture content were higher for triploid fish than for diploid fish ( $\mathrm{p}<0.01$ for exudation and $\mathrm{p}<0.05$ for moisture content).

\subsection{Correlation analysis (Supplemental table S1)}

Fat-meter $^{\circledR}$ values were correlated to raw $(r=0.82, \mathrm{p}<0.001)$ and cooked $(r=0.54, \mathrm{p}<0.001)$ flesh dry matter content. The dry matter content of the raw flesh was positively correlated to that of the cooked flesh $(\mathrm{r}=0.61, \mathrm{p}<0.001)$. These indicators of muscle fat content were positively correlated to color parameters. For example, the raw flesh dry matter content (dmr) was positively correlated to the three color components, $\mathrm{L}^{*}(\mathrm{r}=0.29, \mathrm{p}<0.05), \mathrm{a}^{*}(\mathrm{r}=0.46$, $\mathrm{p}<0.001)$, and $\mathrm{b}^{*}(\mathrm{r}=0.41, \mathrm{p}<0.001)$, measured for raw fillets at $48 \mathrm{~h}$ postmortem. On the contrary, the raw flesh dry matter content was negatively correlated to the raw flesh mechanical resistance $(r=-0.50$ for $\mathrm{MF} / \mathrm{wr}$ and $\mathrm{r}=-0.51$ for $\mathrm{W} / \mathrm{wr}, \mathrm{p}<0.001)$.

The muscle fiber cellularity was correlated to the raw flesh color but not to the cooked flesh 
color. For example, the mean fiber diameter was positively correlated to $\mathrm{L}^{*}(\mathrm{r}=0.48$, $\mathrm{p}<0.001), \mathrm{a}^{*}(\mathrm{r}=0.34, \mathrm{p}<0.001)$ and $\mathrm{b}^{*}(\mathrm{r}=0.39, \mathrm{p}<0.001)$ measured for the raw flesh at $48 \mathrm{~h}$ postmortem. The muscle fiber cellularity was also correlated with some raw flesh mechanical resistance parameters, especially specific resistance $(\mathrm{MF} / \mathrm{wr}, \mathrm{r}=0.60, \mathrm{p}<0.001$ with muscle fiber density), but not with the same parameters measured for cooked flesh. Very few correlations were obtained for $\mathrm{pH}$ values and cooked flesh mechanical resistance parameters.

\section{Discussion}

Intramuscular fat content generally plays a key role in various quality traits of meat and fish products (Hocquette et al., 2010). In rainbow trout, the divergent genetic selection for muscle fat content led to a fish line with consistently distinct muscle fat content. The fish used in the present experiment were obtained after three generations of selection, as described in Quillet et al (2005). After two generations of selection, the muscle lipid content (in $\%$ fresh matter) was increased by $15 \%$ to $31 \%$ in large fish of the F line, depending on the diet (Quillet et al., 2007). Direct measurements of the muscle lipid content confirmed the effect of selection on the next generation. Using low- and high-energy diets, Kolditz et al (2010) recorded an increase of the muscle lipid content of 50\%-60\% in F fish (approximately $180 \mathrm{~g}$ body weight). There was no direct measurement of the muscle fat content on the samples used in the present work, but the muscle lipid content was estimated in diploid fish from the same groups fed the same diet. The difference between the $\mathrm{L}$ and $\mathrm{F}$ fish was in the same range $(5.41 \%$ and $8.72 \%$ of fresh matter in L and F fish, respectively, Quillet et al, unpublished data). Moreover, the two indirect estimations of muscle fat content of the fish in the present experiment (fat-meter value and muscle dry matter content) confirmed that fish used in the present study were significantly different for this trait $(\mathrm{p}<0.001)$, while they had similar weights. In addition, the indirect estimations of muscle fat content indicated that there was also no effect of triploidy on the muscle lipid content, so it was possible to investigate the effect of triploidy per se on 
the fillet quality (no body size or lipid content side effects). Thus, this model appears especially relevant to evaluate the potential impact of divergent selection on the muscle fat content and triploidy on muscle characteristics and fillet organoleptic qualities.

\subsection{Effects of selection for muscle fat content on flesh quality}

This divergent selection had significant effects on the fillet quality measured both by the instrumental technique and the sensory analysis. The salmonid flesh color was determined by the amount and the nature of carotenoid pigments accumulated in the muscle and also by the muscle structure. The relationships between fatness and salmonid muscle color that we observed in this study have already been demonstrated in rainbow trout (Nickell and Bromage, 1998), brown trout (Marty-Mahe et al., 2004) and Atlantic salmon (Einen et al., 1999; Einen and Skrede, 1998). A positive correlation between the muscle fat content and fillet lightness is generally observed during the comparison of fish with various diet-induced adiposity (Einen et al., 1999; Marty-Mahe et al., 2004; Regost et al., 2001a). The lipid accumulation in muscle takes place in the intramuscular adipose tissue, which is a nonpigmented and opaque white tissue. Thus, it seems logical that a fattier muscle would be lighter, and the fat level was shown to be correlated to the myosepta area (Marty-Mahe et al., 2004). Moreover, a positive genetic correlation between fillet lightness and muscle fat content was measured in European whitefish (Kause et al., 2011). Such a correlation is consistent with the higher lightness value measured for the fillets from the fish of the F line, but it remains to be formally demonstrated in rainbow trout. The relationship between muscle fat content and redness and yellowness was more controversial. The increased fat levels of the fillets, resulting from feeding with high-energy diets or high dietary fat levels, were shown to be accompanied by increased redness $\left(\mathrm{a}^{*}\right)$ and yellowness $\left(\mathrm{b}^{*}\right)$ values of brown trout and salmon raw fillets (Einen and Skrede, 1998; Marty-Mahe et al., 2004; Regost et al., 2001a). The increased fillet fat content resulting from the increased feed rations in Atlantic salmon did not 
affect the sensory scores for hue estimation, and color intensity decreased even though the astaxanthin content was higher in the fattier fish (Einen et al., 1999). An explanation of this effect may be the higher solubility properties of carotenoids in a non-polar environment, such as a fattier muscle tissue (Einen and Skrede, 1998).

Fillets from the $\mathrm{L}$ and $\mathrm{F}$ lines also differed in flesh texture, as shown by the mechanical resistance and sensory scores. The selective breeding for muscle fat content significantly affected the mechanical resistance of raw flesh and not that of cooked flesh. The raw fillets of fish from the L line were firmer than those fillets from the F line. After cooking, this effect was no longer observed. The lower firmness of the fattier fish and its relationship with the lipid accumulation in adipose tissues was clearly demonstrated in the cultured yellowtail (Thakur et al., 2003). The lower mechanical resistance of raw fillets from the $\mathrm{F}$ line fish can be explained by a higher proportion of intramuscular adipocytes located within both the perimysium and myosepta of these fish. Adipocytes form a mechanically less resistant tissue, compared to a tissue rich in fibrous proteins such as muscle fibers and connective tissue. Therefore, a higher adipocyte proportion may lower the mechanical resistance through a direct effect because they are less resistant and an indirect effect because they "dilute" the more mechanically resistant proteic tissues (myofibers and connective tissue). In yellowtail, greater lipid deposition in collagenous connective tissue was associated with a low flesh breaking strength, suggesting that the higher lipid deposition in the connective tissue resulted in the weakening of the muscle structure (Thakur et al., 2003). We can note that even with a substantial difference in the muscle lipid content between lines, we observed a limited effect on the textural properties. This may explain the controversial results reported in previous works on salmonids (Johansson et al., 2000; Johnston et al., 2007; Regost et al., 2001a; Robb et al., 2002). Johansson et al. (2000) reported a decisive effect of fat content on fillet texture when comparing rainbow trout with different muscle fat content, obtained by different feeding 
rations. However, Regost et al. (2001a) did not observe a clear difference in raw and cooked fillet quality when they compared brown trout differing in muscle fat content due to a graded amount of dietary fat intake. On the contrary, some significant effects of the muscle lipid content on cooked and smoked fillet texture were observed in Atlantic salmon (Einen et al., 1999; Robb et al., 2002). More recently, Green-Petersen and Hyldig (2010) compared the different groups of large-size (3-4 kg) rainbow trout and found a significant negative phenotypic correlation between the lipid content and firm texture. All of these studies considered big fish (> $2 \mathrm{~kg}$ ) with a significant difference in muscle lipid content (at least $3 \%$ ), and the discrepancy between the muscle content did not explain the different results obtained among studies.

Johnston et al. (2007) reported that Atlantic salmon from two trials exhibited various growth rates, and whether a relationship was observed or not depended on the fish trials. The researchers concluded that genetic and also particularly environmental factors likely influenced the relationship between flesh lipid content and texture. Thus, even if the relationship between the flesh lipid content and the texture was not systematically observed, when an effect was observed, it was always a softer texture associated with a fattier flesh.

Interestingly, a difference in the white muscle cellularity was found. However, fish from the L and $\mathrm{F}$ lines did not differ in their whole body weights. Muscle from the fish of the F line had larger fibers and a lower percent of small fibers than fish from the L line. In Atlantic salmon, a negative genetic correlation was found between the fat content and the muscle fiber density (-0.76) (Vieira et al., 2007). Thus, it appears that selective breeding based on the muscle fat content criteria leads to fish with different muscle cellularity, as a correlated response to genetic selection. This observed difference in the white muscle structure between the two lines can also contribute to the observed difference in the fillet mechanical resistance. The significant negative correlation between the white muscle fibers size and the fillet firmness 
was already observed in previous studies with raw fillets of rainbow trout (Lefevre et al., 2008), brown trout (Bugeon et al., 2003), and smoked fillets from Atlantic salmon (Johnston et al., 2000). The higher white muscle fibers size in fish from the F line may also contribute to the higher exudation detected by the sensorial analysis for fillets from F line fish. Indeed, a weak but significant correlation between the smoked fillet dryness and muscle fiber density $\left(\mathrm{R}^{2}=0.12, \mathrm{p}<0.05\right)$ was previously reported in Atlantic salmon (Johnston et al., 2000).

Other differences in the fillet quality between fish from the $\mathrm{L}$ and $\mathrm{F}$ lines were revealed by the sensorial analysis. Some of the differences were directly related to the distinct fillet fat content between the two lines, such as more fat droplets in the exudate, more exudation or a more fatty film on the tongue in fillets from fish of the F line. A more pronounced flavor of cooked potatoes was also a feature of fillets from $\mathrm{F}$ fish. A significant effect of muscle fat content on the flavor is often observed with salmonid fillets and is particularly pronounced for smoked fillets (Einen et al., 1999; Einen and Skrede, 1998; Johansson et al., 2000; Robb et al., 2002).

\subsection{Effects of triploidy on flesh quality}

The application of triploidization in salmonid fish has been shown to affect many aspects of fish biology (Benfey, 1999; Piferrer et al., 2009). Among the main effects observed were a larger nuclei with a concomitant increase in cell volume in triploid fish (Benfey, 1999; Piferrer et al., 2009). From the flesh quality point of view, this biological particularity of triploid fish may affect the structural organization of muscle tissue by causing larger muscle fibers. In the present study, we observed that triploid fish had larger white muscle fibers than diploid fish ( $+9 \%$ and $+15 \%$ of the mean diameter for the $\mathrm{L}$ line and $\mathrm{F}$ line, respectively). Such an effect of triploidy on muscle fibers size was already reported in salmonids (Bjørnevik et al., 2004; Johnston et al., 1999; Poontawee et al., 2007; Sigurgisladottir et al., 2001; Suresh and Sheehan, 1998). In the present study, higher values of lightness were found for both raw 
and cooked fillets of triploid fish. Such a difference may be related to the higher muscle fiber size in triploid fish, as fillet lightness was correlated to fiber size, at least for raw fillets, in the present study. However, the effect of ploidy on fillet color is still controversial and seems to depend on fish size. Brighter fillets for triploid fish were also obtained with pan-size rainbow trout (Werner et al., 2008). However, such an effect of triploidy on fillet lightness was not observed with larger (900 g) rainbow trout (Choubert et al., 1997), and darker fillets in triploid fish were even observed in large (> $2 \mathrm{~kg}$ ) rainbow trout (Poontawee et al., 2007) and Atlantic salmon (Bjørnevik et al., 2004). Thus, the muscle fiber size may have an impact on the fillet lightness, but this parameter does not seem to be the main determinant.

The higher value of the ultimate $\mathrm{pH}$, the lowest value measured during the postmortem evolution, was also observed for triploid fish fillets at $48 \mathrm{~h}$ postmortem. This may be due to the lower glycogen stores in triploid fish muscle, but this parameter was not measured in the present study. A positive correlation between the ultimate $\mathrm{pH}$ and glycolytic potential was reported in trout (Lefevre et al., 2008). An opposite effect of triploidy on the ultimate $\mathrm{pH}$ value was observed with 1.4-6.5 kg Atlantic salmon (Bjørnevik et al., 2004).

Fillets from triploid fish were less firm than diploid fillets for both the raw and cooked fillets. This result can be related to the larger muscle fibers of triploid fish, as previously discussed (Bugeon et al., 2003; Johnston et al., 2000; Lefevre et al., 2008). Moreover, the softer flesh of the cooked fillets of triploids was especially observed in fish from the F line. This suggested a cumulative effect of the higher lipid content and triploidy status on muscle fiber size to induce a softer flesh. In previous studies, the lower firmness of the triploid fish fillet was often related to the higher muscle or body fat content of triploid fish (Bjørnevik et al., 2004; Poontawee et al., 2007). We could presume that in the present study, there was no difference in muscle fat content between $2 \mathrm{n}$ and $3 \mathrm{n}$ fish because we found no difference in the muscle dry matter content, and these two parameters are strongly and positively correlated (Crossin 
and Hinch, 2005). A significant difference in the muscle fat content between $2 \mathrm{n}$ and $3 \mathrm{n}$ fish was reported for older fish when 2n fish became sexually mature (Aussanasuwannakul et al., 2011). The lower firmness of triploid fish fillets has already been reported in sexually mature rainbow trout (Aussanasuwannakul et al., 2011) and in Atlantic salmon (Bjørnevik et al., 2004) but not in any other studies with fresh and smoked salmon (Sigurgisladottir et al., 2001). The difference in the firmness in the sensory analysis was not significant, but fillets from triploid fish gave more exudation and were moister. However, the main difference measured in the sensory analysis between $2 \mathrm{n}$ and $3 \mathrm{n}$ fish was a lower global intensity of odor for $3 \mathrm{n}$ fish fillets $(\mathrm{p}<0.001)$. To our knowledge, such an effect has never been observed when comparing diploid and triploid fish. The possible effect of the beginning of gametogenesis, associated with secretion of sexual steroids, remains to be studied in diploid fish.

Some differences between $2 \mathrm{n}$ and $3 \mathrm{n}$ fish were observed in the flesh quality but may be less pronounced than those observed with larger fish. At the pan size, the $2 \mathrm{n}$ fish were not sexually mature yet, and only a limited effect of sexual maturation on the flesh quality was observed. Thus, the effect of triploid can be measured, per se, and we can presume that the difference would become more and more evident as the fish mature, as sexual maturation affects the physiology and muscle characteristics of diploid fish.

Very few interactions were observed between the effect of selection and the effect of ploidy. Thus, the effect of divergent selection we measured on the fillet quality was equivalent in diploid and triploid fish. Therefore, the genetic selection for muscle fat content performed in diploid fish can be applied to large triploid fish.

\subsection{Relationship between flesh quality parameters}

The groups of fish compared in the present study differed mainly in (1) muscle fat content, as they were issued from a divergent selection for this feature, and (2) ploidy with consequences observed on the muscle fiber size. This set of data allowed us to explore the correlations 
between the muscle fat content or fiber size, and flesh quality parameters. The raw fillet color was positively correlated to the muscle fibers size parameters, suggesting an implication of the muscle structure in color determinism. However, the color parameters were also positively correlated to the flesh dry matter content. This correlation may be due to a higher content of carotenoid pigments in the flesh of fattier fish, as previously observed in salmon (Einen et al., 1999). The fattier fish from the $\mathrm{F}$ line also had larger muscle fibers than leaner fish. Therefore, it is difficult to conclude what the specific involvement of larger muscle fibers was on more colorful flesh. The color of the cooked flesh was correlated to that of the raw flesh, which allowed a partial prediction of this parameter based on the raw flesh properties.

Low correlations were measured between the cooked fillet mechanical resistance and other muscle characteristics. A negative correlation was observed between the cooked flesh specific resistance and both initial and ultimate $\mathrm{pH}(\mathrm{r}=-0.28$ and $\mathrm{r}=-0.32, \mathrm{p}<0.05$ for initial and ultimate $\mathrm{pH}$, respectively), and a positive correlation was measured with the cooked dry matter content $(\mathrm{r}=0.32, \mathrm{p}<0.05)$. Thus, the results from the present study do not provide a conclusive explanation of trout cooked flesh determinism.

On the contrary, the mechanical resistance parameters for the raw flesh were correlated to the muscle fiber size. For example, the specific resistance (MF/wr) was positively correlated to the proportion of small fibers $(\mathrm{r}=0.46, \mathrm{p}<0.001)$ and negatively correlated to the proportion of the large fibers $(\mathrm{r}=-0.51, \mathrm{p}<0.001)$ and fiber mean diameter $(\mathrm{r}=-0.57, \mathrm{p}<0.001)$. The present study confirmed a relationship between the muscle fiber size and the raw flesh firmness, as discussed above. The specific resistance of raw flesh was also positively correlated to the initial $\mathrm{pH}(\mathrm{r}=0.46, \mathrm{p}<0.001)$ and negatively correlated to the raw muscle dry matter content $(\mathrm{r}=-0.50, \mathrm{p}<0.001)$. Therefore, both the muscle lipid content and the muscle fiber size contributed to the mechanical resistance of the raw flesh.

\section{Conclusions}


Selective breeding for muscle fat content affected the organoleptic qualities of pan-size rainbow trout. The raw fillets from fatty fish (F line) were more colorful and less firm than fillets from lean fish (L line). The instrumental and sensorial analyses did not detect any differences in the firmness of cooked fillets. The sensory evaluation discriminated the fillets from the two lines based on some criteria, including appearance, flavor, exudation and moisture content. Triploid fish had softer raw and cooked fillets, according to the instrumental evaluation, but this difference was not perceived by the sensory panel. The sensorial evaluations revealed a lower global intensity of odor, more exudation and a higher moisture content in the fillets from the triploid fish. All of these effects were associated with the larger white muscle fibers in fish from the F line and in triploid fish. The significant effects of selective breeding and triploidy were demonstrated on both the muscle composition and structure. These effects must be taken into account for the purpose of controlling fish quality by rearing practices.

\section{Acknowledgements}

The present study was funded by INRA and IFREMER and the grant AQS NCF24 from the French Research Ministry.

The authors thank all the staff of the PEIMA facilities for fish rearing and for their technical assistance for slaughter measurements and Gilles Paboeuf and Josiane Cornet for technical assistance in the quality measurements in the laboratory.

\section{References}

Aksnes, A. 1995. Growth, feed efficiency and slaughter quality of salmon, Salmo salar L., given feeds with different ratios of carbohydrate and protein. Aquaculture Nutrition 1: 241-248.

Atkins, M. E., and T. J. Benfey. 2008. Effect of acclimation temperature on routine metabolic rate in triploid salmonids. Comparative Biochemistry and Physiology A-Molecular \& 
Integrative Physiology 149: 157-161.

Aussanasuwannakul, A. et al. 2011. Effect of sexual maturation on growth, fillet composition, and texture of female rainbow trout (Oncorhynchus mykiss) on a high nutritional plane. Aquaculture 317: 79-88.

Bell, J. G. et al. 2010. Growth, flesh adiposity and fatty acid composition of Atlantic salmon (Salmo salar) families with contrasting flesh adiposity: Effects of replacement of dietary fish oil with vegetable oils. Aquaculture 306: 225-232.

Benfey, T. J. 1999. The physiology and behavior of triploid fishes. Reviews in Fisheries Science 7: 39-67.

Bjørnevik, M., M. Espe, C. Beattie, R. Nortvedt, and A. Kiessling. 2004. Temporal variation in muscle fibre area, gaping, texture, colour and collagen in triploid and diploid Atlantic salmon (Salmo salar L). Journal of the Science of Food and Agriculture 84: 530-540.

Bugeon, J., F. Lefevre, and B. Fauconneau. 2003. Fillet texture and muscle structure in brown trout (Salmo trutta) subjected to long-term exercise. Aquaculture Research 34: 12871295.

Chaiyapechara, S., M. T. Casten, R. W. Hardy, and F. M. Dong. 2003a. Fish performance, fillet characteristics, and health assessment index of rainbow trout (Oncorhynchus mykiss) fed diets containing adequate and high concentrations of lipid and vitamin E. Aquaculture 219: 715-738.

Chaiyapechara, S., K. K. M. Liu, F. T. Barrows, R. W. Hardy, and F. M. Dong. 2003b. Proximate composition, lipid oxidation, and sensory characteristics of fillets from rainbow trout Oncorhynchus mykiss fed diets containing 10\% to 30\% lipid. Journal of the World Aquaculture Society 34: 266-277.

Chan, J. C. K. et al. 2002. Effects of feeding diets containing various dietary protein and lipid 
ratios on the growth performance and pigmentation of post-juvenile coho salmon Oncorhynchus kisutch reared in sea water. Aquaculture Research 33: 1137-1156.

Choubert, G., J. M. Blanc, and F. Vallee. 1997. Colour measurement, using the CIELCH colour space, of muscle of rainbow trout, Oncorhynchus mykiss (Walbaum), fed astaxanthin: Effects of family, ploidy, sex, and location of reading. Aquaculture Research 28: 15-22.

Chourrout, D. 1984. Pressure-induced retention of second polar body and suppression of first cleavage in rainbow trout: Production of all-triploids, all-tetraploids, and heterozygous and homozygous diploid gynogenetics. Aquaculture 36: 111-126.

Corraze, G., L. Larroquet, and F. Medale. 1999. Alimentation et dépots lipidiques chez la truite arc-en-ciel, effet de la température d'élevage. INRA Productions Animales 12: 249-256.

Crossin, G. T., and S. G. Hinch. 2005. A nonlethal, rapid method for assessing the somatic energy content of migrating adult pacific salmon. Transactions of the American Fisheries Society 134: 184-191.

Das, S., B. N. Paul, J. Sengupta, and A. K. Datta. 2009. Beneficial effects of fish oil to human health: a review. Agricultural Reviews 30: 199-205.

Daviglus, M. L. et al. 1997. Fish consumption and the 30-year risk of fatal myocardial infarction. New England Journal of Medicine 336: 1046-1053.

Douirin, C., P. Haffray, J. L. Vallet, and B. Fauconneau. 1998. Determination of the lipid content of rainbow trout (Oncorhynchus mykiss) fillets with the Torry Fish Fat Meter (R). Sciences des aliments 18: 527-535.

Einen, O., T. Mørkøre, A. M. B. Rørå, and M. S. Thomassen. 1999. Feed ration prior to slaughter - a potential tool for managing product quality of Atlantic salmon (Salmo salar). Aquaculture 178: 149-169. 
Einen, O., and G. Skrede. 1998. Quality characteristics in raw and smoked fillets of Atlantic salmon, Salmo salar, fed high-energy diets. Aquaculture Nutrition 4: 99-108.

Fauconneau, B. et al. 1993. Characteristics of rainbow trout flesh .2. Physical and sensory aspects. Sciences des aliments 13: 189-199.

Golik, W., O. Dameron, J. Bugeon, A. Fatet, I. Hue, C. Hurtaud, M. Reichstadt, M.C. Meunier-Salaün, J. Vernet, L Joret, F. Papazian, C. Nédellec and P.Y. Le Bail. ATOL: the multi-species livestock trait ontology. $6^{\text {th }}$ International Conference on Metadata and Semantic Research, 28-30 Nov.2012, Cadiz, Spain (2012)

Gomez-Guillén, M. C., P. Montero, O. Hurtado, and A. J. Borderias. 2000. Biological characteristics affect the quality of farmed Atlantic salmon and smoked muscle. Journal of Food Science 65: 53-60.

Green-Petersen, D. M. B., and G. Hyldig. 2010. Variation in sensory profile of individual rainbow trout (Oncorhynchus mykiss) from the same production batch. Journal of Food Science 75: S499-S505.

Hocquette, J. F. et al. 2010. Intramuscular fat content in meat-producing animals: development, genetic and nutritional control, and identification of putative markers. Animal 4: 303-319.

ISO, International Organization for Standardization 1988. Sensory analysis - General guidance for the design of test rooms, ISO 8589, Geneva, Switzerland.

Johansson, L., A. Kiessling, K. H. Kiessling, and L. Berglund. 2000. Effects of altered ration levels on sensory characteristics, lipid content and fatty acid composition of rainbow trout (Oncorhynchus mykiss). Food Quality and Preference 11: 247-254.

Johnston, I. A. et al. 2000. Muscle fibre density in relation to the colour and texture of smoked Atlantic salmon (Salmo salar L.). Aquaculture 189: 335-349.

Johnston, I. A. et al. 2007. Fast growth was not associated with an increased incidence of soft 
flesh and gaping in two strains of Atlantic salmon (Salmo salar) grown under different environmental conditions. Aquaculture 265: 148-155.

Johnston, I. A., G. Strugnell, M. L. Mccracken, and R. Johnstone. 1999. Muscle growth and development in normal-sex-ratio and all-female diploid and triploid Atlantic salmon. Journal of Experimental Biology 202: 1991-2016.

Kause, A., C. Quinton, S. Airaksinen, K. Ruohonen, and J. Koskela. 2011. Quality and production trait genetics of farmed European whitefish, Coregonus lavaretus. Journal of Animal Science 89: 959-971.

Kolditz, C. et al. 2008. Liver and muscle metabolic changes induced by dietary energy content and genetic selection in rainbow trout (Oncorhynchus mykiss). American Journal of Physiology - Regulatory Integrative and Comparative Physiology 294: R1154-R1164.

Kolditz, C. I., E. Plagnes-Juan, E. Quillet, F. Lefevre, and F. Medale. 2010. Changes in white muscle transcriptome induced by dietary energy levels in two lines of rainbow trout (Oncorhynchus mykiss) selected for muscle fat content. British Journal of Nutrition 103: $629-642$.

Lefevre, F., J. Bugeon, B. Auperin, and J. Aubin. 2008. Rearing oxygen level and slaughter stress effects on rainbow trout flesh quality. Aquaculture 284: 81-89.

Lopez-De Leon, A., and M. Rojkind. 1985. A simple micromethod for collagen and total protein determination in formalin-fixed paraffin-embedded sections. Journal of Histochemistry \& Cytochemistry 33: 737-743.

Marty-Mahe, P. et al. 2004. Quality traits of brown trouts (Salmo trutta) cutlets described by automated color image analysis. Aquaculture 232: 225-240.

Medale, F., F. Lefevre, and G. Corraze. 2003. Nutritional and health promoting value of fish: main factors affecting flesh components - Qualité nutritionnelle et diététique des 
poissons, constituants de la chair et facteurs de variation. Cahier de Nutrition et Diététique 38: 37-44.

Mørkøre, T. et al. 2001. Fat content and fillet shape of Atlantic salmon: Relevance for processing yield and quality of raw and smoked products. Journal of Food Science 66: $1348-1354$.

Nickell, D. C., and N. R. Bromage. 1998. The effect of dietary lipid level on variation of flesh pigmentation in rainbow trout (Oncorhynchus mykiss). Aquaculture 161: 237-251.

Piferrer, F. et al. 2009. Polyploid fish and shellfish: Production, biology and applications to aquaculture for performance improvement and genetic containment. Aquaculture 293: $125-156$.

Poontawee, K., C. Werner, A. Muller-Belecke, G. Horstgen-Schwark, and M. Wicke. 2007. Flesh qualities and muscle fiber characteristics in triploid and diploid rainbow trout. Journal of Applied Ichthyology 23: 273-275.

Quillet, E., S. Le Guillou, J. Aubin, and B. Fauconneau. 2005. Two-way selection for muscle lipid content in pan-size rainbow trout (Oncorhynchus mykiss). Aquaculture 245: 4961.

Quillet, E. et al. 2007. Response of a lean muscle and a fat muscle rainbow trout (Oncorhynchus mykiss) line on growth, nutrient utilization, body composition and carcass traits when fed two different diets. Aquaculture 269: 220-231.

Regost, C., J. Arzel, M. Cardinal, M. Laroche, and S. J. Kaushik. 2001a. Fat deposition and flesh quality in seawater reared, triploid brown trout (Salmo trutta) as affected by dietary fat levels and starvation. Aquaculture 193: 325-345.

Regost, C. et al. 2001b. Dietary lipid level, hepatic lipogenesis and flesh quality in turbot (Psetta maxima). Aquaculture 193: 291-309.

Robb, D. H. F., S. C. Kestin, P. D. Warriss, and G. R. Nute. 2002. Muscle lipid content 
determines the eating quality of smoked and cooked Atlantic salmon (Salmo salar). Aquaculture 205: 345-358.

Sigurgisladottir, S., M. S. Sigurdardottir, H. Ingvarsdottir, O. J. Torrissen, and H. Hafsteinsson. 2001. Microstructure and texture of fresh and smoked Atlantic salmon, Salmo salar L., fillets from fish reared and slaughtered under different conditions. Aquaculture Research 32: 1-10.

Solberg, C. 2004. Influence of dietary oil content on the growth and chemical composition of Atlantic salmon (Salmo salar). Aquaculture Nutrition 10: 31-37.

Suresh, A. V., and R. J. Sheehan. 1998. Muscle fibre growth dynamics in diploid and triploid rainbow trout. Journal of Fish Biology 52: 570-587.

Szczesniak, A. S., P. R. Humbaugh, and H. W. Block. 1970. Behavior of different foods in the standard shear compression cell of the shear press and the effect of sample weigth on peak area and maximum force. Journal of Texture Studies 1: 356-378.

Thakur, D. P., K. Morioka, Y. Itoh, and A. Obatake. 2003. Lipid composition and deposition of cultured yellowtail Seriola quinqueradiata muscle at different anatomical locations in relation to meat texture. Fisheries Science 69: 487-494.

Tobin, D. et al. 2006. Fat or lean? The quantitative genetic basis for selection strategies of muscle and body composition traits in breeding schemes of rainbow trout (Oncorhynchus mykiss). Aquaculture 261: 510-521.

Vieira, V. L. A., A. Norris, and I. A. Johnston. 2007. Heritability of fibre number and size parameters and their genetic relationship to flesh quality traits in Atlantic salmon (Salmo salar L.). Aquaculture 272: S100-S109.

Weil, C., F. Lefevre, and J. Bugeon. 2013. Characteristics and metabolism of different adipose tissues in fish. Reviews in Fish Biology and Fisheries 23: 157-173.

Werner, C., K. Poontawee, A. Mueller-Belecke, G. Hoerstgen-Schwark, and M. Wicke. 2008. 
Flesh characteristics of pan-size triploid and diploid rainbow trout (Oncorhynchus mykiss) reared in a commercial fish farm. Archiv fur Tierzucht-Archives of Animal Breeding 51: 71-83. 
$\underline{\text { Table } 1}$ : Effects of divergent selection for muscle fat content and ploidy on fish characteristics and fillet quality parameters immediately after death. Mean \pm standard deviation, $\mathrm{n} \geq 45$.

\begin{tabular}{|c|c|c|c|c|c|c|c|}
\hline Line : & \multicolumn{2}{|r|}{$\mathbf{L}$} & \multicolumn{2}{|c|}{$\mathbf{F}$} & \multirow{2}{*}{$\begin{array}{c}\text { Line } \\
\text { effect }\end{array}$} & \multirow{2}{*}{$\begin{array}{l}\text { Ploidy } \\
\text { effect }\end{array}$} & \multirow[t]{2}{*}{$1 \times 2$} \\
\hline Ploidy : & $2 n$ & $3 n$ & $2 n$ & $3 n$ & & & \\
\hline BW (g) & $302 \pm 66$ & $286 \pm 56$ & $290 \pm 55$ & $288 \pm 56$ & NS & NS & NS \\
\hline $\mathbf{K}$ & $1.43 \pm 0.13^{\mathrm{a}}$ & $1.44 \pm 0.13^{\mathrm{a}}$ & $1.49 \pm 0.15^{\mathrm{a}}$ & $1.47 \pm 0.11^{\mathrm{a}}$ & $* *$ & NS & $\mathrm{NS}$ \\
\hline Fat (\%) & $5.97 \pm 0.91^{b}$ & $6.02 \pm 1.19^{b}$ & $11.45 \pm 1.78^{\mathrm{a}}$ & $11.19 \pm 1.71^{\mathrm{a}}$ & $* * *$ & $\mathrm{NS}$ & $\mathrm{NS}$ \\
\hline $\mathbf{L}^{*}$ & $43.3 \pm 2.0^{c}$ & $43.6 \pm 2.3^{b c}$ & $44.2 \pm 1.8^{b}$ & $45.3 \pm 2.3^{\mathrm{a}}$ & $* * *$ & $*$ & $\mathrm{NS}$ \\
\hline $\mathbf{a}^{*}$ & $9.2 \pm 1.5^{b}$ & $9.0 \pm 1.5^{b}$ & $9.9 \pm 1.2^{\mathrm{a}}$ & $10.2 \pm 1.3^{\mathrm{a}}$ & $* * *$ & NS & NS \\
\hline $\mathbf{b}^{*}$ & $14.4 \pm 1.8^{b}$ & $14.1 \pm 1.8^{b}$ & $15.1 \pm 1.7^{\mathrm{a}}$ & $15.2 \pm 1.8^{\mathrm{a}}$ & *** & NS & NS \\
\hline pHi & $6.79 \pm 0.18^{\mathrm{a}}$ & $6.72 \pm 0.17^{b}$ & $6.70 \pm 0.13^{b}$ & $6.72 \pm 0.18^{\mathrm{ab}}$ & $\mathrm{p}=0.06$ & NS & $\mathrm{p}=0.06$ \\
\hline
\end{tabular}

$\mathrm{L}$ : lean line, $\mathrm{F}$ : fat line, $2 \mathrm{n}$ : diploid, $3 \mathrm{n}$ : triploid fish, $1 \times 2$ : interaction between selection effect and ploidy

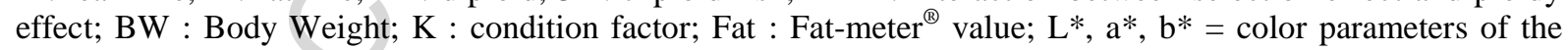
fillet, $\mathrm{L}^{*}$ : lightness, $\mathrm{a}^{*}$ : redness, $\mathrm{b}^{*}$ : yellowness; $\mathrm{pHi}:$ initial muscle $\mathrm{pH}$. NS : not significant $(\mathrm{p}>0.05), *$ : $\mathrm{p}<0.05, * *: \mathrm{p}<0.01, * * *: \mathrm{p}<0.001 ; \mathrm{p}=$ probability. Values with the same letter in the same row are not significantly different $(\mathrm{p}>0.05)$. 
Table 2 : Effects of divergent selection for muscle fat content and ploidy on flesh dry matter content, $\mathrm{pH}$, and color of raw and cooked flesh at 48h (raw) and 96h (cooked) postmortem. Mean \pm standard deviation, $\mathrm{n}=15$.

\begin{tabular}{|c|c|c|c|c|c|c|c|}
\hline \multirow{2}{*}{$\begin{array}{c}\text { Line : } \\
\text { Ploidy : }\end{array}$} & \multicolumn{2}{|c|}{$\mathbf{L}$} & \multicolumn{2}{|c|}{$\mathbf{F}$} & \multirow{2}{*}{$\begin{array}{l}\text { Line } \\
\text { effect }\end{array}$} & \multirow{2}{*}{$\begin{array}{c}\text { Ploidy } \\
\text { effect }\end{array}$} & \multirow[t]{2}{*}{$1 \times 2$} \\
\hline & $2 n$ & $3 n$ & $2 n$ & $3 n$ & & & \\
\hline \multicolumn{8}{|c|}{ Raw flesh : } \\
\hline DMC (\%) & $27.0 \pm 1.1^{b}$ & $26.8 \pm 0.9^{b}$ & $29.6 \pm 1.5^{\mathrm{a}}$ & $30.2 \pm 1.3^{\mathrm{a}}$ & $* * *$ & NS & NS \\
\hline pHu & $6.41 \pm 0.03^{\mathrm{a}}$ & $6.44 \pm 0.06^{\mathrm{a}}$ & $6.41 \pm 0.05^{\mathrm{a}}$ & $6.44 \pm 0.06^{\mathrm{a}}$ & NS & * & $\mathrm{NS}$ \\
\hline $\mathbf{L}^{*}$ & $41.3 \pm 1.5^{\mathrm{a}}$ & $42.7 \pm 2.2^{\mathrm{a}}$ & $42.2 \pm 1.8^{\mathrm{a}}$ & $43.0 \pm 1.8^{\mathrm{a}}$ & NS & * & NS \\
\hline $\mathbf{a}^{*}$ & $9.3 \pm 1.4^{b}$ & $9.6 \pm 1.1^{b}$ & $10.0 \pm 1.0^{\mathrm{ab}}$ & $10.7 \pm 1.3^{\mathrm{a}}$ & $* *$ & NS & NS \\
\hline $\mathbf{b}^{*}$ & $14.0 \pm 2.1^{b}$ & $14.8 \pm 1.5^{\mathrm{ab}}$ & $14.9 \pm 1.5^{\mathrm{ab}}$ & $15.8 \pm 1.5^{\mathrm{a}}$ & $*$ & $\mathrm{p}=0.053$ & $\mathrm{NS}$ \\
\hline Delta pH & $0.46 \pm 0.11^{\mathrm{a}}$ & $0.33 \pm 0.14^{b}$ & $0.32 \pm 0.15^{b}$ & $0.29 \pm 0.16^{b}$ & $*$ & $*$ & NS \\
\hline \multicolumn{8}{|c|}{ Cooked flesh : } \\
\hline DMC (\%) & $28.8 \pm 1.5^{\mathrm{ab}}$ & $27.9 \pm 1.0^{b}$ & $30.0 \pm 1.9^{\mathrm{a}}$ & $29.7 \pm 1.5^{\mathrm{a}}$ & $* * *$ & NS & NS \\
\hline pHc & $6.69 \pm 0.07$ & $6.70 \pm 0.07$ & $6.68 \pm 0.04$ & $6.68 \pm 0.05$ & NS & $\mathrm{NS}$ & $\mathrm{NS}$ \\
\hline $\mathbf{L}^{*}$ & $69.4 \pm 3.3^{b}$ & $72.8 \pm 3.8^{\mathrm{a}}$ & $72.3 \pm 2.5^{\mathrm{a}}$ & $72.3 \pm 3.0^{\mathrm{a}}$ & $\mathrm{NS}$ & $*$ & 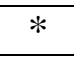 \\
\hline $\mathbf{a}^{*}$ & $14.4 \pm 2.6^{\mathrm{a}}$ & $14.6 \pm 2.2^{\mathrm{a}}$ & $15.5 \pm 1.6^{\mathrm{a}}$ & $16.5 \pm 2.7^{\mathrm{a}}$ & $*$ & NS & NS \\
\hline $\mathbf{b}^{*}$ & $24.8 \pm 3.1^{b}$ & $25.9 \pm 2.6^{\mathrm{ab}}$ & $26.8 \pm 2.9^{\mathrm{ab}}$ & $28.3 \pm 3.8^{\mathrm{a}}$ & $*$ & NS & NS \\
\hline
\end{tabular}

$\mathrm{L}$ : lean line, F : fat line, $2 \mathrm{n}$ : diploid, $3 \mathrm{n}$ : triploid fish, $1 \times 2$ : interaction between selection effect and ploidy effect; DMC : Dry Matter Content; $\mathrm{pHu}$ : ultimate muscle $\mathrm{pH}$; Delta $\mathrm{pH}=\mathrm{pHu}-\mathrm{pHi} ; \mathrm{pHc}$ : cooked muscle $\mathrm{pH} ; \mathrm{L}^{*}$, $a^{*}, b^{*}=$ color parameters of the fillet, $L^{*}:$ lightness, $a^{*}$ : redness, $b^{*}:$ yellowness; NS : not significant $(p>0.05)$, $*: \mathrm{p}<0.05, * * *: \mathrm{p}<0.001 ; \mathrm{p}=$ probability. Values with the same letter in the same row are not significantly different $(\mathrm{p}>0.05)$. 
$\underline{\text { Table 3 }}$ : Effects of divergent selection for muscle fat content and ploidy on raw and cooked fillet mechanical resistance parameters. Mean \pm standard deviation, $\mathrm{n}=15$.

\begin{tabular}{|c|c|c|c|c|c|c|c|}
\hline Line : & \multicolumn{2}{|c|}{$\mathbf{L}$} & \multicolumn{2}{|c|}{$\mathbf{F}$} & \multirow{2}{*}{$\begin{array}{c}\text { Line } \\
\text { effect }\end{array}$} & \multirow{2}{*}{$\begin{array}{r}\text { Ploidy } \\
\text { effect }\end{array}$} & \multirow[t]{2}{*}{$1 \times 2$} \\
\hline Ploidy : & $2 n$ & $3 n$ & $2 n$ & $3 n$ & & & \\
\hline \multicolumn{8}{|c|}{ Raw flesh : } \\
\hline $\begin{array}{c}\text { Fmax/w } \\
\left(N^{\prime} \cdot g^{-1}\right)\end{array}$ & $13.2 \pm 2.1^{\mathrm{a}}$ & $11.7 \pm 1.6^{\mathrm{ab}}$ & $12.2 \pm 1.9^{\mathrm{ab}}$ & $10.9 \pm 1.6^{\mathrm{b}}$ & $\mathrm{p}=0.06$ & $* *$ & NS \\
\hline 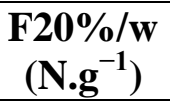 & $0.51 \pm 0.12$ & $0.53 \pm 0.16$ & $0.53 \pm 0.11$ & $0.49 \pm 0.10$ & NS & NS & NS \\
\hline $\begin{array}{c}\text { F80\%/w } \\
\left(N^{\prime} \cdot g^{-1}\right)\end{array}$ & $7.35 \pm 0.89$ & $7.18 \pm 0.60$ & $7.39 \pm 0.87$ & $7.16 \pm 0.77$ & NS & NS & NS \\
\hline $\begin{array}{l}W / w \\
(J / g)\end{array}$ & $540 \pm 93^{\mathrm{a}}$ & $507 \pm 62^{\mathrm{ab}}$ & $479 \pm 48^{\mathrm{bc}}$ & $434 \pm 39^{c}$ & $* * *$ & $*$ & NS \\
\hline \multicolumn{8}{|c|}{ Cooked flesh : } \\
\hline $\begin{array}{c}\text { Fmax/w } \\
\left(\mathbf{N} \cdot g^{-1}\right)\end{array}$ & $25.8 \pm 4.4^{\mathrm{ab}}$ & $25.4 \pm 3.3^{\mathrm{ab}}$ & $28.3 \pm 6.8^{\mathrm{a}}$ & $23.1 \pm 4.3^{b}$ & NS & $*$ & $\mathrm{p}=0.06$ \\
\hline $\begin{array}{c}\text { F20\%/w } \\
\left(N^{\prime} \cdot g^{-1}\right)\end{array}$ & $0.59 \pm 0.18^{\mathrm{a}}$ & $0.57 \pm 0.15^{\mathrm{a}}$ & $0.68 \pm 0.12^{\mathrm{a}}$ & $0.54 \pm 0.12^{\mathrm{a}}$ & NS & $*$ & $\mathrm{p}=0.10$ \\
\hline $\begin{array}{c}\text { F80\%/w } \\
\left({\left.\mathrm{N} . \mathrm{g}^{-1}\right)}\right.\end{array}$ & $7.47 \pm 1.10^{\mathrm{a}}$ & $7.66 \pm 1.08^{\mathrm{a}}$ & $7.96 \pm 1.27^{\mathrm{a}}$ & $7.05 \pm 0.68^{\mathrm{a}}$ & NS & NS & $*$ \\
\hline $\begin{array}{l}W / w \\
(J / g)\end{array}$ & $910 \pm 177^{\mathrm{a}}$ & $927 \pm 147^{\mathrm{a}}$ & $986 \pm 249^{\mathrm{a}}$ & $838 \pm 177^{\mathrm{a}}$ & NS & NS & $\mathrm{p}=0.10$ \\
\hline
\end{tabular}

$\mathrm{L}$ : lean line, F : fat line, $2 \mathrm{n}$ : diploid, $3 \mathrm{n}$ : triploid fish, $1 \times 2$ : interaction between selection effect and ploidy effect; Fmax $/ \mathrm{w}=$ maximal force $/$ sample weight; F20\%/w = Force at $20 \%$ deformation $/$ sample weight;: $\mathrm{F} 80 \% / \mathrm{w}=$ Force at $80 \%$ deformation $/$ sample weight; W/w $=$ Work until Fmax / sample weight; NS : not significant $(\mathrm{p}>0.05), *: \mathrm{p}<0.05, * *: \mathrm{p}<0.01 ; * * *: \mathrm{p}<0.001 ; \mathrm{p}=$ probability. Values with the same letter in the same row are not significantly different $(\mathrm{p}>0.05)$. 
$\underline{\text { Table } 4}$ : Effects of divergent selection for muscle fat content and ploidy on white muscle fiber density (Dens.), mean diameter (MD), percentage of small fibers (diameter < $20 \mu \mathrm{m}$ ), and percentage of big fibers (diameter $>100 \mu \mathrm{m}$ ). Mean \pm standard deviation, $\mathrm{n}=15$.

\begin{tabular}{|c|c|c|c|c|c|c|c|}
\hline Line : & \multicolumn{2}{|c|}{$\mathbf{L}$} & \multicolumn{2}{|c|}{$\mathbf{F}$} & \multirow{2}{*}{$\begin{array}{c}\text { Line } \\
\text { effect }\end{array}$} & \multirow{2}{*}{$\begin{array}{c}\text { Ploidy } \\
\text { effect }\end{array}$} & \multirow[t]{2}{*}{$1 \times 2$} \\
\hline Ploidy : & $2 n$ & $3 n$ & $2 n$ & $3 n$ & & & \\
\hline $\begin{array}{c}\text { Dens. } \\
(\text { fib/mm²) }\end{array}$ & $470 \pm 79^{a}$ & $383 \pm 65^{b}$ & $442 \pm 70^{\mathrm{a}}$ & $330 \pm 52^{c}$ & * & $* * *$ & NS \\
\hline M D $(\mu \mathrm{m})$ & $45.4 \pm 3.9^{c}$ & $50.0 \pm 5.7^{b}$ & $46.3 \pm 3.9^{c}$ & $54.7 \pm 5.1^{\mathrm{a}}$ & $*$ & $* * *$ & $\mathrm{NS}$ \\
\hline $\begin{array}{c}\text { \% small fibers } \\
(<20 \mu \mathrm{m})\end{array}$ & $22.6 \pm 5.4^{\mathrm{a}}$ & $22.1 \pm 5.5^{\mathrm{a}}$ & $21.8 \pm 5.1^{\mathrm{a}}$ & $16.6 \pm 5.9^{b}$ & * & $\mathrm{p}=0.051$ & $\mathrm{p}=0.09$ \\
\hline $\begin{array}{c}\text { \% large fibers } \\
(>100 \mu \mathrm{m})\end{array}$ & $7.6 \pm 5.0^{\mathrm{b}}$ & $15.3 \pm 6.8^{\mathrm{a}}$ & $9.3 \pm 4.8^{\mathrm{b}}$ & $18.5 \pm 4.2^{\mathrm{a}}$ & $\mathrm{p}=0.08$ & $* * *$ & NS \\
\hline
\end{tabular}

$\mathrm{L}$ : lean line, F : fat line, $2 \mathrm{n}$ : diploid, $3 \mathrm{n}:$ triploid fish, $1 \times 2$ : interaction between selection effect and ploidy effect; NS : not significant ( $>0.05), *: p<0.05, * * *: p<0.001 ; p=$ probability. Values with the same letter in the same row are not significantly different $(\mathrm{p}>0.05)$. 
F Lefèvre et al.

Selection for muscle lipid content ...

$\underline{\text { Table } 5}$ : Effects of divergent selection for muscle fat content and ploidy on sensorial analysis for cooked flesh.

Mean sensory score assessed on a continuous scale from low intensity ( 0 ) to high intensity (10), $\mathrm{n}=18$ panelists.

\begin{tabular}{|c|c|c|c|c|c|c|c|}
\hline \multirow{2}{*}{$\begin{array}{l}\text { Line : } \\
\text { Ploidy : }\end{array}$} & \multicolumn{2}{|c|}{$\mathbf{L}$} & \multicolumn{2}{|c|}{$\mathbf{F}$} & \multirow{2}{*}{$\begin{array}{l}\text { Line } \\
\text { effect }\end{array}$} & \multirow{2}{*}{$\begin{array}{l}\text { Ploidy } \\
\text { effect }\end{array}$} & \multirow{2}{*}{$1 \times 2$} \\
\hline & $2 n$ & $3 n$ & $2 n$ & $3 n$ & & & \\
\hline \multicolumn{8}{|l|}{ Odor : } \\
\hline $\begin{array}{l}\text { Global } \\
\text { intensity }\end{array}$ & $5.3 \pm 1.5$ & $4.8 \pm 1.4$ & $5.7 \pm 1.8$ & $4.4 \pm 1.7$ & NS & $* * *$ & NS \\
\hline Fat fish & $3.7 \pm 2.0$ & $3.3 \pm 2.1$ & $3.6 \pm 2.4$ & $3.2 \pm 1.8$ & $\mathrm{NS}$ & NS & $\mathrm{NS}$ \\
\hline Milky & $1.7 \pm 1.3$ & $1.8 \pm 1.4$ & $1.7 \pm 1.6$ & $2.1 \pm 1.4$ & $\mathrm{NS}$ & NS & $\mathrm{NS}$ \\
\hline $\begin{array}{l}\text { Cooked } \\
\text { potato }\end{array}$ & $1.6 \pm 1.8$ & $1.8 \pm 1.9$ & $1.9 \pm 1.8$ & $1.5 \pm 1.4$ & NS & NS & NS \\
\hline Earthy & $1.4 \pm 1.9$ & $1.4 \pm 2.0$ & $1.2 \pm 2.2$ & $0.6 \pm 0.6$ & $\mathrm{NS}$ & NS & NS \\
\hline \multicolumn{8}{|l|}{ Appearance : } \\
\hline $\begin{array}{l}\text { Orange } \\
\text { colour }\end{array}$ & $4.4 \pm 2.3$ & $4.3 \pm 1.7$ & $5.1 \pm 2.0$ & $4.4 \pm 2.1$ & NS & NS & NS \\
\hline $\begin{array}{l}\text { Density of } \\
\text { the flesh }\end{array}$ & $5.4 \pm 2.2$ & $5.1 \pm 2.2$ & $1 \pm 1.8$ & $4.9 \pm 2.0$ & NS & NS & NS \\
\hline $\begin{array}{c}\text { Fat droplets } \\
\text { in exudate }\end{array}$ & $4.0 \pm 2.0$ & $4.6 \pm 1.7$ & $6.2 \pm 1.8$ & $5.8 \pm 1.8$ & $* * *$ & NS & NS \\
\hline \multicolumn{8}{|l|}{ Flavour : } \\
\hline $\begin{array}{c}\text { Global } \\
\text { intensity }\end{array}$ & $4.9 \pm 1.6$ & $5.3 \pm 1.6$ & $5.0 \pm 1.5$ & $4.9 \pm 1.6$ & NS & NS & NS \\
\hline Fat fish & $3.8 \pm 2.0$ & $4.4 \pm 2.0$ & $4.1 \pm 2.3$ & $4.1 \pm 2.1$ & $\mathrm{NS}$ & NS & NS \\
\hline $\begin{array}{l}\text { Cooked } \\
\text { potato }\end{array}$ & $1.1 \pm 1.0$ & $1.3 \pm 1.2$ & $1.7 \pm 1.2$ & $1.7 \pm 1.5$ & $* * *$ & NS & NS \\
\hline Earthy & $1.2 \pm 1.4$ & $1.0 \pm 1.1$ & $1.1 \pm 1.5$ & $0.9 \pm 1.3$ & $\mathrm{NS}$ & NS & NS \\
\hline Bitter & $0.6 \pm 1.4$ & $0.4 \pm 0.7$ & $0.5 \pm 0.9$ & $0.5 \pm 0.7$ & NS & NS & NS \\
\hline Metallic taste & $0.3 \pm 0.4$ & $0.3 \pm 0.4$ & $0.6 \pm 0.6$ & $0.4 \pm 0.6$ & $\mathrm{NS}$ & NS & NS \\
\hline \multicolumn{8}{|c|}{ Texture : } \\
\hline Firmness & $3.9 \pm 1.2$ & $3.7 \pm 1.8$ & $3.5 \pm 1.5$ & $3.2 \pm 1.8$ & NS & NS & NS \\
\hline Fracturability & $4.2 \pm 2.2$ & $3.9 \pm 2.1$ & $4.0 \pm 2.4$ & $4.1 \pm 2.3$ & $\mathrm{NS}$ & NS & NS \\
\hline Exudation & $3.0 \pm 1.9$ & $4.1 \pm 1.9$ & $4.0 \pm 2.0$ & $4.4 \pm 2.0$ & $*$ & $* *$ & $\mathrm{p}=0.08$ \\
\hline $\begin{array}{l}\text { Perception of } \\
\text { fibres }\end{array}$ & $4.7 \pm 2.0$ & $4.4 \pm 1.9$ & $4.6 \pm 1.9$ & $4.4 \pm 2.0$ & NS & NS & NS \\
\hline $\begin{array}{l}\text { Moisture } \\
\text { Content }\end{array}$ & $3.4 \pm 2.1$ & $4.7 \pm 1.8$ & $4.6 \pm 1.7$ & $4.8 \pm 2.0$ & $*$ & $*$ & $\mathrm{p}=0.06$ \\
\hline Pasty texture & $2.8 \pm 2.2$ & $2.4 \pm 1.8$ & $2.6 \pm 2.0$ & $2.5 \pm 2.4$ & $\mathrm{NS}$ & NS & NS \\
\hline $\begin{array}{l}\text { Sticky } \\
\text { texture }\end{array}$ & $4.2 \pm 2.4$ & $3.6 \pm 2.5$ & $4.4 \pm 2.5$ & $4.0 \pm 2.5$ & NS & NS & NS \\
\hline $\begin{array}{l}\text { Fatty film on } \\
\text { tongue }\end{array}$ & $2.0 \pm 1.5$ & $2.1 \pm 1.5$ & $2.6 \pm 1.7$ & $3.0 \pm 1.6$ & $*$ & NS & NS \\
\hline
\end{tabular}

$\mathrm{L}:$ lean line, $\mathrm{F}:$ fat line, $2 \mathrm{n}:$ diploid, $3 \mathrm{n}:$ triploid fish, $1 \times 2$ : interaction between selection effect and ploidy effect; NS : not significant $(\mathrm{p}>0.05), *: \mathrm{p}<0.05, * *: \mathrm{p}<0.01 ; * * *: \mathrm{p}<0.001 ; \mathrm{p}=$ probability. 